\title{
Determinants of Successful Cooperation in Agricultural Markets: Evidence from Producer Groups in Poland
}

\author{
Ilona Banaszak
}

\begin{abstract}
The main question posed in the paper is why some cooperative arrangements in agricultural markets survive and succeed while others fail. Data were collected from 62 Polish farmer cooperative organizations called producer groups. The main aim of those organizations was to organize joint sales of output produced individually by their members. Some of the groups were functioning effectively while others had disbanded or were no longer performing their essential functions. Variables such as the leader's strength, previous business acquaintances, initial selection of members, and number of members have a significant positive impact on the likelihood of success of the researched organizations.
\end{abstract}

Keywords: Cooperation · Agricultural markets · Producer groups · Poland

\section{Introduction}

In the mid-1990s organizations called producer groups first appeared in Poland. Producer groups were formed by farmers, and their main purpose was to jointly sell agricultural output produced individually by members. Farmers entering producer groups kept their distinct property rights, and they coordinated only on some transactions such as searching for buyers, negotiating contracts and transportation. The groups adopted different legal forms ranging from informal oral agreements, through associations, unions, limited liability companies and cooperatives.

\footnotetext{
I. Banaszak

Humboldt University Berlin, Division of Resource Economics, Luisenstr. 56, 10099 Berlin, Germany

and

Slovak Academy of Sciences, Institute for Forecasting, Sancova 56, 81105 Bratislava, Slovakia

banaszai@rz.hu-berlin.de
} 
Data from an empirical survey carried out with leaders of producer groups located in Wielkopolska Province show a substantial variety in the performance of producer groups. First of all, at the time the research was carried out $20 \%$ of the groups were disbanded. Second, only $80 \%$ of functioning groups performed the main task of organizing joint sales of the output produced individually by memberfarmers; others were engaged only in organizing such activities as joint transportation, joint purchase of the means of production, organizing trainings for members and other social events. Third, some of the functioning groups that performed joint sales were not able to negotiate any price premium for their members' output and were selling their products at the same price as non-members farmers; others were able to negotiate as much as a $39 \%$ higher price premium for their members (Banaszak, 2006).

The central question posed in this article is why such big differences among the producer groups exist. Why do some of the cooperative organizations fail over time, why do some continue to exist without performing their main functions, and why do others expand and build up their market power?

The success and failure of cooperative enterprises in agricultural markets has been subjected to empirical research; however, the literature merely focuses on organizations that were operating and performing their main tasks at the time the research was carried out. What also emerges from the literature review is that the authors define success of cooperative organizations in very different terms. Bruynis et al. (1997), for instance, executed an empirical survey with 52 American marketing cooperatives and distinguished eight keys to success, understood in terms of longevity, business growth, profitability, and member satisfaction. Such factors as implementation of a management training process, employing an experienced fulltime general manager, regularly distributing accurate financial statements among the management team, using marketing agreements to secure business volume commitments from the members, and utilizing human resources appeared to be significant for the researched organizations achieving success (Bruynis et al., 1997: 54). Sexton and Iskow (1988), who built their study around vertical integration theory, distinguished three groups of organizational, financial, and operational keys to success of agricultural cooperatives. The authors surveyed 61 U.S. agricultural cooperatives and asked the respondents to rank their cooperatives on a four-level success scale. Such factors as open membership, accepting nonmember business, and employing full-time management were correlated with self-understood success.

Among research including disbanded organizations, we find Ziegenhorn (1999), who based his research on economic anthropology and New Institutional Economics and carried out a few case studies of farmer production networks in the swine industry. The author also investigated cases of actors failing to cooperate. The greatest responsibility for a network's success or failure in terms of its survival was attributed to a network organizer whose knowledge and selection of participating farmers influenced compatibility (Ziegenhorn, 1999: 66).

Producer groups are only one possible way of organizing transactions between farmers and purchasers of their products. Another way is a direct exchange or an exchange through a middleman. We discuss the comparative advantage of one form of 
organization versus others and review both internal and external factors that might either facilitate or hinder cooperation. We divide the producer groups subjected to research into four categories of success: (a) disbanded groups, (b) groups functioning but not performing their main function of organizing joint sales of members' output, (c) functioning groups performing joint sales, but having problems with members shirking the group agreements and selling their output outside the group without group permission, and (d) groups performing joint sales and having no problems with members deceiving group rules. Factors related to group governance appear to have the most significant impact on the likelihood of achieving such understood success.

The paper is organized as follows: Sect. 2 provides a theoretical framework for investigating the success and failure of cooperative organizations such as producer groups, and identifies hypotheses to be tested further. Section 3 presents the methodology of the research, and Sect. 4 presents the empirical evidence. Finally, Section 5 concludes and discusses the results.

\section{Literature Review and Hypotheses}

\subsection{Governance of the Relationship Between Farmers and Purchasers}

Regarding the implementation of their main task - that is, organizing joint sales of the output produced by individual member farmers - producer groups act as intermediary market organizations that coordinate the exchange of goods and services between farmers and purchasers of their produce. Intermediaries are firms that seek out suppliers, find and encourage purchasers, select buy and sell prices, organize the transactions, keep the records, and hold inventories to supply liquidity or availability of goods and services (Spulber, 1999: 3). Intermediaries appear on the market if the net gains from trade exceed those obtained through direct exchange. The profit of intermediaries is raised by identifying innovative transactions that either increase gains from trade or reduce transaction costs associated with search, negotiation, communication, computation, contracting, and monitoring the transaction and its partners (Spulber, 1999: 259, 260). Producer groups take the role traditionally fulfilled on the market by middlemen and other traders. Nonetheless, the advantage to producer groups, which puts them in competition with middlemen and traders, is eliminating double marginalization and the potential savings on transaction costs offered to the farmers associated in producer groups due to horizontal and vertical integration. Horizontal integration occurs between different businesses located on the same level of the channel (Caputo and Mininno, 1996: 64) and, in producer groups, takes place due to the association of farmers into one organization. Vertical integration occurs between businesses located at different stages of the channel (Caputo and Mininno, 1996: 64) and, in producer groups, takes place whenever the groups move down in the market channel while organizing joint transportation 
Decentralized exchange

Farmer 1 Farmer 2 Farmer 3

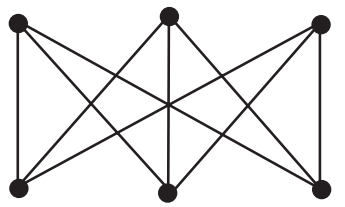

Centralized exchange: intermediary

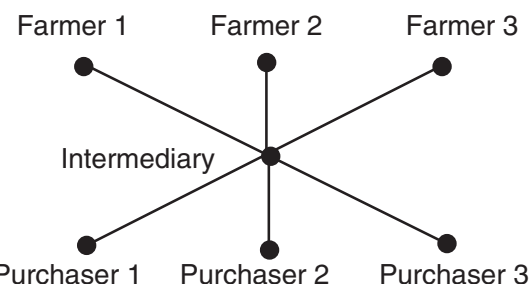

Purchaser 1 Purchaser 2 Purchaser 3 Purchaser 1 Purchaser 2 Purchaser 3

\section{Centralized exchange: producer group}

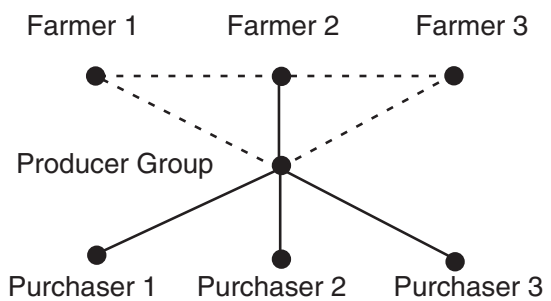

Fig. 1 Exchange with and without an intermediary and a producer group between farmers and purchasers of their output. Source: Adapted from Spulber (1999: 264)

or processing the produce. The main intermediary function of producer groups is therefore coordinating an exchange of goods and services between individual member farmers and purchasers of the farmers' agricultural output (Fig. 1). Producer groups also undertake the intermediary function in organizing such activities as joint purchases of the means of production or joint transportation.

Nonetheless, producer groups are not classic firms. Firms integrate property rights, thus subsuming all transaction costs related to the production of goods and/or services (Ménard, 2005: 294). Farmers associated in producer groups do not integrate property rights and do not merge their farms into one organization. Each of them individually makes the final decision on how to produce the good and when and to whom to sell it. Producer groups of informal character cannot even sign any official agreement with purchasers on behalf of farmers, since they do not have a legal form recognized by law. Such hybrid arrangements, in between market and firm modes of governance, cover only a subset of the transactions in which participating firms are involved (Ménard, 2005: 294). In hybrid organizations functioning in agriculture, the advantage of keeping separate ownership rights and not merging farmers into one farming enterprise is that due to idiosyncratic knowledge specific for farming it would be impossible for a company to accurately judge the quality of farmers' inputs (Bonus, 1986: 331-331).

Based on the comparison of different modes of governance of the transactions, we may propose that successful producer groups will be those that manage to coordinate the exchange between farmers and purchasers and that additionally operate at per unit costs not exceeding the per unit costs of organizing the transaction through alternative ways, such as decentralized exchange or intermediation by other agents. 


\subsection{Factors Affecting the Likelihood of Success of Producer Groups}

Several authors discuss factors that may contribute to the formation of successful cooperative arrangements. One such factor is group size. The level of transaction costs can be decreased by increasing the frequency of transactions. The more frequently the transaction takes place, the lower the fixed costs per unit (Ménard, 2006: 28). In a producer group situation, frequency of transactions can be raised through increasing the number of members. Additionally, enlarging the number of organization members might decrease the danger of opportunistic behavior and internal rent seeking by members since it implies a lower share in the organization's profits for each individual and discourages internal rent seeking. Those organizations that survive are not the most profitable but are most successful at solving problems of internal rent seeking (Kräkel, 2006: 2, 21). The parameter is closely related to influence costs participants spend to influence activities in an attempt to affect the distribution of quasi rents (Milgrom, 1988: 43, Schaefer, 1998: 238-239). Influence costs tend to be higher when the group members have larger stakes in the decision to be made (Milgrom, 1988: 43). Nonetheless, decreasing transaction and influence costs by enlarging the number of group members increases internal coordination and bureaucracy costs. Producer groups should therefore have to bear the costs of coordinating farmer actions and organizing production, marketing, and administration. As pointed out by Olson (1965: 59-60), larger groups find it harder to communicate and coordinate their actions. Kollock (1998: 201) points out that too many parameters change in tandem with group size and thus assessing the impact of this parameter might be problematic.

Hypothesis 1. The number of members in producer groups has an indeterminate impact on the likelihood of achieving success by producer groups.

Internal coordination costs might be decreased by leadership. A strong central coordinator enables the group to save on both total transaction information transmission and decision-making costs (Williamson, 1983: 41, 45). Several authors point out that irrespectively of game setting leadership is a factor that facilitates cooperation. In coordination games, leadership as a form of hierarchy helps to coordinate member actions on one of multiple equilibria, and therefore lowers bargaining costs that players would have to spend to agree on and implement one of the strategies (Miller, 1992: 50). Some social arrangements arise as inefficient equilibria of repeated games and endure because no one would benefit from a unilateral change (Binger and Hoffman, 1989: 68). A leader could facilitate coordination of the players through a simultaneous move to a more efficient equilibrium. Leadership might also provide additional utility from reciprocating cooperation (Foss, 1999: 13, 22; Shamir et al., 1993: 577). Due to additional utility from reciprocating cooperation, the payoff structure in a prisoners' dilemma game might be transformed into a coordination game. Strong leaders might also make the threat of punishing shirking players more feasible. Banaszak and Beckmann (2006: 17) show that leaders' decision-making power was significantly correlated with exercising sanctions 
in producer groups in Poland. Given effective threats and an appropriate reputation, a leader with enhanced capabilities can employ a trigger strategy to initiate and sustain cooperative behavior of followers in repeated prisoner's dilemma plays (Bianco and Bates, 1990: 144). Leadership could also improve observability of members' decisions and actions. Under the above circumstances cheating on implicit agreements becomes less attractive (Hendrikse, 2007: 142). However, developing an adequate information system among partners also matters. An overly-strong, dominant leader who can capture information is a threat to the continuity of the relationship in hybrid forms of governance (Ménard, 2004: 351).

Hypothesis 2. A stronger leader contributes to saving on internal transaction and coordination costs and thus is expected to have a positive impact on the likelihood of the formation of successful producer groups up to a point; however, an overlystrong, dominant leader reduces the likelihood of success.

As pointed out by Ménard (2004: 351), sharing rents in hybrids involves the danger of opportunistic behavior that can potentially provoke conflicts. Therefore, the identity of partners is important and their selection is a key element. In most cases, the selection of partners is based on previous experience in market relationships, on previous hybrid arrangements, and/or on reputation (Ménard, 2004: 361). Hence, we may expect that both the selection of alliance partners and previous business relationships will have an impact on the formation of successful producer groups. A similar argument is put forward by Whipple and Frankel (2000), who discuss strategic alliances. Firms implementing alliances have problems with the transition from an adversarial to a cooperative relationship; the changes in mind-set, culture, and behavior can be overwhelming. The largest barrier to alliance success is organizational culture. It is the greatest cost for alliances, and it takes a long time to modify partners' traditional habits and beliefs while adopting new ways of conducting business (Whipple and Frankel, 2000: 22). Ahn et al. (2001: 137) show that in a one-shot prisoner's dilemma experiment, success in coordinating on the payoff dominant equilibrium in previous plays of coordination games has a positive impact on the probability of cooperating in the prisoner's dilemma game. Groups in which players interact more durably or frequently increase identifiably, and information about individuals' past actions are expected to cause higher cooperation (Axelrod, 1984: 62-63).

Hypothesis 3. Selection of members having a previous business relationship between them is expected to have a positive impact on the likelihood of the formation of successful producer groups.

In a similar way, communication structures may encourage better exchange of information about the individuals involved in the interaction. Kollock (1998) mentions a number of studies that point out that communication promotes cooperation. Communication allows group members to make explicit commitments and promises about their future moves and to appeal to the "right" or "proper" thing to do, thus exerting moral pressure. Similarly to leadership, communication could also increase the observability of others' actions and decrease the attractiveness of 
cheating. Brosig and Weimann (2003) examine communication effects in public goods experiments that only differ with respect to pre-play communication. The results indicate that successful cooperation might be attributed to the opportunity to coordinate behavior in the communication phase. However, the success of communication depends strongly on the communication medium. The results show that the most efficient is face-to-face communication. Interestingly, it did not make a difference whether people were sitting at the same table or watching each other on a video screen (Brosig and Weimann, 2003: 217, 231).

Hypothesis 4. Communication among members is expected to have a positive impact on the likelihood of producer groups achieving success.

Furthermore, authors also discuss the role of group composition. Hansmann (1996: 125-130) argues that member homogeneity of any kind implies that members will have more interest in common and is an essential factor for successful cooperation. Opposing interests between members and engaging in internal lobbying to promote selfish interests increase influence costs in a cooperative organization (Borgen, 2004: 387). Kleindorfer et al. (1993: 247-251) point out that homogeneous groups with similarities in the partners' potential power and interests are more likely to achieve a higher cooperation rate. Haag and Lagunoff (2003: 21) examine characteristics of cooperative behavior in a repeated prisoner's dilemma game and provide arguments that homogenous groups in respect to time preferences of their members are more cooperative. The larger the differences in players' time preferences, the less cooperative is the group (Haag and Lagunoff, 2003: 7).

Hypothesis 5. Members' homogeneity is expected to have a positive impact on the likelihood of achieving success by producer groups.

Banaszak and Beckmann (2006) point out that some variables related to the environment in which cooperation takes place and to group structure might either facilitate or hinder cooperation. One of the factors which might decrease the likelihood of achieving successful cooperation is competition. Competition with other intermediaries might increase the likelihood of deviation from group rules expressed through sales outside, and thus decreases the likelihood of achieving success by producer groups. A volatile environment may raise the attractiveness of a short-run gain of defection in relation to the obedience to the long-run implicit contract (Hendrikse, 2007: 142). In such conditions defection of one group member might also result in a cascade of defection by others, since everyone else sees less value in the initial choice. This effect will be stronger in small organizations and if returns to scale in coordination more rapidly decrease (Kreps, 1996: 585). Competition may destabilize hybrid forms, since the partners might be tempted to switch among arrangements, particularly if investments in the cooperation are only moderately specific (Ménard, 2005: 295-296). Hybrids, however, tend to develop in highly competitive markets in which pooling resources is a way to survive and to decrease uncertainty (Ménard, 2005: 295). Competition is beginning to shift from firm versus firm to supply chain versus supply chain, which creates the need for integration strategies 
(Bowersox et al., 1999). The problem that hybrids face is therefore which mechanism to adopt in order to delineate joint decisions, discipline partners, and solve conflicts while preventing free riding (Ménard, 2005: 295-296). On the one hand, competition might increase the likelihood of producer group formation; on the other, the resultant instability of the arrangements may affect the likelihood of success.

Hypothesis 6. Competition may destabilize cooperative arrangements and thus is expected to have a negative impact on the likelihood of achieving success by producer groups.

\section{Research Methods}

\subsection{Sample and Data Collection}

In order to test the hypotheses we collected data on producer groups functioning in the Wielkopolska Province. The chosen province of Wielkopolska is one of 16 provinces in Poland and is located in the western part of the country. The crosssectional research design was selected as a research method for this investigation. This design employed the technique of social survey, which uses a structured interview with producer group leaders as the data collection strategy. Fifty functioning groups and 12 disbanded groups were subjected to the research. The 50 functioning groups associated 4,056 farmers; the 12 inactive ones associated 394 farmers. The interviews were carried out in early 2005.

The structured interview with producer group leaders was organized into a questionnaire composed of six sections which addressed: (a) general information about the group such as the group's address, legal status, number of members, and activities performed, (b) the process of group formation, (c) group functioning (divided into three sections: management and decision-making, production and marketing, and membership), (d) costs and benefits of cooperation, (e) the role of the institutional environment, and (f) leadership. These six sections comprised 132 questions in total. Two types of questions were asked: the first was related to facts such as numbers or descriptions of processes, the second to the subjective evaluation of these facts.

\subsection{Measuring "Success"}

As reviewed in Sect. 1, different definitions have been applied to measure success and failure of cooperative enterprises. Bruynis et al. (1997) define success in terms of longevity, business growth, profitability, and members' satisfaction. Sexton and Iskow (1988) measure success based on self-evaluation. Ziegenhorn (1999) understands success of networks in terms of their survival. In Sect. 2.1 we proposed 
measuring the success of producer groups in terms of being able to coordinate the exchange between farmers and purchasers and additionally to operate at per unit costs, which do not exceed per the unit costs of organizing the transaction through alternative ways. Such an understanding of success could be measured by either investigating the price premium that the groups negotiate for the members' output, or by investigating whether the benefits of the groups' functioning are higher than its costs. Price premium was measured by questioning percent difference between the price obtained by group members for their products and that obtained by nonmember farmers on the market. On average, producer group members were selling their products at a $6.2 \%$ higher price premium. Twenty-seven groups were either not selling jointly at all or were selling their products at a 0 price premium. Two groups were able to negotiate a price premium as high as $39.3 \%(\mathrm{SD}=10.32)$. Regarding whether producer groups were obtaining higher benefits than operation costs, the question was coded as a dummy variable, in which 1 stood for having higher benefits than operation costs. Fifty-one percent of the interviewed producer group leaders classified their groups as obtaining higher benefits from operation than costs.

However, the above measurements do not differentiate between groups which were no longer functioning and those that did not organize joint sales of the output produced by member-farmers. We may thus also propose grouping the researched organizations according to their performance. The first category which can be distinguished by such an approach is disbanded groups which are clear examples of failure. Twelve groups that disbanded were identified in the research process. Some producer groups continued functioning, despite failing to coordinate their members on joint sales. Such groups were only engaged in organizing such activities as joint purchases of the means of production or training and educational activities. Coordination on these activities is more likely to be achieved, and the group actions are less vulnerable to market conditions; however, benefits from organizing such activities are expected to be lower than from organizing joint sales. We therefore propose including these groups into the second category of partial failure. The groups failed to coordinate farmers on the activity which could potentially bring higher profits but still provided their members some collective action benefits. Within the research process we have identified ten such groups.

The remaining 40 groups performed joint sales but what is interesting is that most of the groups had problems with members deviating from group rules and selling their products outside the group without group permission. Such actions suggest that these groups were not able to convince their members that they had the best possible market arrangements, and outside options were more attractive to the members. Within this category of partial success we identified 33 groups. The last category of full success consisted of seven groups which were performing joint sales and did not have problems with members shirking from the group agreements.

Below we present how the identified measurements of producer group success correspond to each other. For comparison of the distinguished based on the theory categories with self-perception of the actors involved in cooperation, we also include a self-evaluated measure of success suggested by Sexton and Iskow (1988). The interviewed producer group leaders could rank their groups as a major success, 
Fig. 2 Correlations between the variables indicating different measures of producer group success

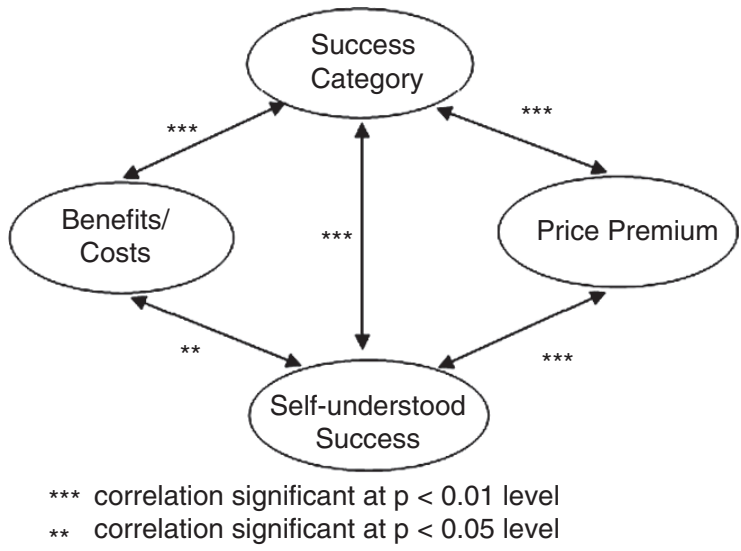

a minor success, "too early to say," or unsuccessful. Forty percent of the interviewees classified their groups as unsuccessful (ranked as 0 ), $8 \%$ as "too early to say" (ranked as 1), 27.4\% as having achieved minor success (ranked as 2), and 24.2\% as having achieved major success (ranked as 3). Most of the leaders (40.3\%) understood self-evaluated success or failure of their groups in terms of the ability to profitably market member output. For $24.2 \%$ success or failure of their groups was understood in terms of the ability to function, and $17.7 \%$ in terms of the ability to get farmers together. Other groups evaluated their success or failure in terms of achieving initial goals $(6.4 \%)$, obtaining subsidies $(4.8 \%)$, acquiring investments $(3.2 \%)$, and achieving good product quality (3.2\%).

Since the variable indicating four categories of success was the only one correlated at the most significant level with the remaining variables, we decided to use this variable in the subsequent empirical analysis (Fig. 2).

\subsection{Analysis}

An ordinal probit model was employed in the research. The ordinal regression model is a nonlinear model in which the magnitude of change in the outcome probability for a given change in one of the independent variables depends on the levels of all of the independent variables (Long and Freese, 2001: 137). The distinguished four categories of the success of producer groups are treated in the model as an ordinal dependent variable (S). The hypothesis formulated in Sect. 2.2 pointed out that such variables as the number of group members (NM), leadership strength (Lead), selection of members (Sel), business acquaintance (Buis), communication among members (Com), member homogeneity (Hom), and competition (Comp) will impact the likelihood of the formation of successful cooperative arrangements. The 
variables are expected to influence the likelihood of achieving success by producer groups according to the model:

$$
S_{i}=\beta_{0}+\beta_{1} N M+\beta_{2} \text { Lead }+\beta_{3} \text { Sel }+\beta_{4} \text { Buis }+\beta_{5} \text { Com }+\beta_{6} \text { Hom }+\beta 7 \text { Comp }+\varepsilon_{i}
$$

where $i=1, \ldots, n$ producer groups in the sample.

Section 4.2 operationalizes and presents summary statistics for the distinguished independent variables. Additionally, in order to compare differences in the mean values of variables characterizing the categories of success, we have used one-way analysis of variance (ANOVA). ANOVA involves one independent variable (referred to as a factor), which has a number of different levels. These levels correspond to the distinguished different groups. ANOVA compares the variance (variability in scores) between the different groups (believed to be due to the independent variable) with the variability within each of the groups (believed to be due to chance). A significant $F$ test indicates that we can reject the null hypothesis, which states that means across the groups are equal (Pallant 2001: 186).

\section{Empirical Results}

\subsection{Characteristic of the Dependent Variable}

We treat the distinguished categories of success as the dependent variable. In Sect. 4.2 we are going to test the impact of the hypothesis suggested in Sect. 2 on the likelihood of achieving success. However, before we do so, in this section we would like to provide a description of the dependent variable and explore the differences between the four distinguished categories in respect to basic characteristics of producer groups such as the year of establishment, number of members, impetus for formation, level of initial level of invested capita, legal form, type of members' production, and activities performed. We use the ANOVA technique in order to compare whether the differences in the basic characteristics across the distinguished categories are statistically significant.

The mean establishment year for the groups was 1999. The majority of the groups which did not operate at the time the interview was carried, stopped their activity in 2001. On average each disbanded group was functioning for 2.8 years. Regarding the factors which resulted in splitting up, the interviewed producer groups leaders most frequently pointed to the so-called "mentality of the people" problem. It had to do with commitment, loyalty and trust in the leader and other members. Two groups did not want to change their purchasers to those appointed by the leader, and in three cases the members did not want to compensate the leader for his work or to hire a manager. Regarding other cases, two groups reported having problems with finding purchasers; one group was destroyed by a middleman who offered members a higher price if they sold their output outside the group; in one case the group was embedded in a conflict between two neighboring villages, and inhabitants of one village spread false information about the leader in order to destroy the group; and 
in the last case the leader pocketed the groups' money and members did not want to continue cooperation afterwards.

On average each of the interviewed groups had 72 farmers associated with it. Most of the groups had been initiated by one of the farmers $(58 \%)$; the other $42 \%$ had been initiated by an outside organization, $24 \%$ by the extension service and $18 \%$ by outside businessmen such as processing companies, local agricultural cooperatives or middlemen. Regarding the legal form adopted by the producer groups, the groups can be informal or take any legal form of economic or social entrepreneurship defined by Polish law. The biggest share of the producer groups were functioning as associations (29\%). Associations are voluntary and self-governing organizations established to fulfill noneconomic goals. Associations can represent their members in relations with institutions cooperating with farmers and negotiate prices or contracts with purchasers or sellers on behalf of the farmers. This form can be established very easily and has a simple structure. Its biggest disadvantage, however, is its inability to cumulate profits and share capital among members; members are not owners of the accumulated capital (Lemanowicz, 2005: 103).

Twenty-three percent of the groups adopted the legal form of a union and the same portion chose a Limited Liability Company (LLC). Unions are voluntary, selfgoverning, and independent social and vocational organizations, established to represent and protect farmers' interests. Similarly to associations, the establishment of a union is simple and fast and requires no start-up capital (Lemanowicz, 2005: 103). Changes in the group constitution can be introduced quite cheaply. Unions can run economic activity, but all profits must be divided equally among the members (Ejsmont and Milewski, 2005: 66). A LLC can be established for any purpose. Its members purchase shares, the amount of which defines their decision-making power and their liability. Shareholders are owners of the company, and the accumulated capital can be divided among them according to the number of shares purchased. The process of an LLC's establishment and operation is more complicated and costly. Its establishment and any changes must be officially registered in a notary office (Lemanowicz, 2005: 104).

The least popular forms were informal groups and cooperatives. Eight percent of the groups were informal and 3\% were functioning as cooperatives. The main purpose of a cooperative is to run an economic activity. Similarly to an LLC, members purchase shares in the cooperative. The property of the cooperative is the private property of its members, and members can withdraw the value of their shares at any time. Each member has equal decision-making power, which limits the decisionmaking impact of major shareholders. Both LLCs and cooperatives must maintain full bookkeeping.

On average each group collected 6,461 EUR as start-up capital (365 EUR per member). The most frequent type of output produced by members was pork $(56 \%)$, vegetables $(21 \%)$, and fruits $(6 \%)$. The task of organizing joint sales of the output produced by member-farmers was carried out by $65 \%$ of the groups. Fifty-five percent of the groups also organized joint supplies of the means of production, and $29 \%$ organized joint transportation of the goods. Other tasks performed by producer groups included arranging training and educational activities for members 
(performed by $65 \%$ of the groups), integration events (45\%), and arranging subsidies offered from the government and EU budget (27\%).

Table 1 presents a summary of characteristics of the identified producer group categories. A series of one-way analyses of variance ANOVA was run in order to identify whether there were any significant differences in the mean scores of the variables presented in Table 1 for the distinguished categories of success. A significant difference in mean scores indicated the variable representing whether the group was formed from the initiative of the extension service $(F(3,58)=2.4, p=0.077)$. The effect size was 0.11 . The significant difference was between Category 1 and Category 4. It suggests that considerably more groups that failed were initiated by the extension service than groups that achieved success. The mean scores for choosing the legal form of association were also significantly different at $p<0.05$ level $(F(3,58)=3.7, p=0.16)$. The effect size was 0.10 . The significant differences were between Category 1, Category 3 , and Category 4 , which suggest that the governance form of association is more frequent among groups that failed than among those that achieved either partial or full success.

Regarding the question of why the form of association was chosen, again we see a large impact of the extension service. Thirty percent of groups functioning as associations chose this form due to advice of the extension service. Others chose it because it was considered a "loose" form, which did not require capital investments (17\%), because it was a cheap form (13\%), because it was considered to provide a sufficient level of security $(8 \%)$, or because farmers were not aware that there are other forms available $(8 \%)$.

We find a slightly significant but negative correlation between the choice of the legal form of association and the level of invested capital $(p<0.1)$. This suggests that maybe the level of capital invested in associations was too small to enable the group to survive in the market. One such investment could be paying a salary to the leader for organizing the task of joint sales. A very significant negative correlation is found between choosing the legal form of association and paying a salary to the leader $(p<0.01)$. Additionally, as discussed by Banaszak and Beckmann (2007: 186 ), leaders of producer groups who did not receive a salary were less likely to negotiate a high price premium.

Regarding the type of production of the member farmers, the mean scores for only one variable - that is, producing vegetables - differed significantly at $p<0.1$ level $(F(3,58)=2.28, p=0.089)$. The effect size was medium and equalled to 0.10 . The difference was between Category 2 and Category 4. Vegetables are a more frequent type of production among successful groups than among those that suffered a partial failure.

\subsection{Characteristic of the Independent Variables}

In this section we present how we operationalize the independent variables derived from theory in Sect. 2. Regarding group size, each group associated an average of 71 members. Group sizes, however, were greatly disproportionate, which is indicated 


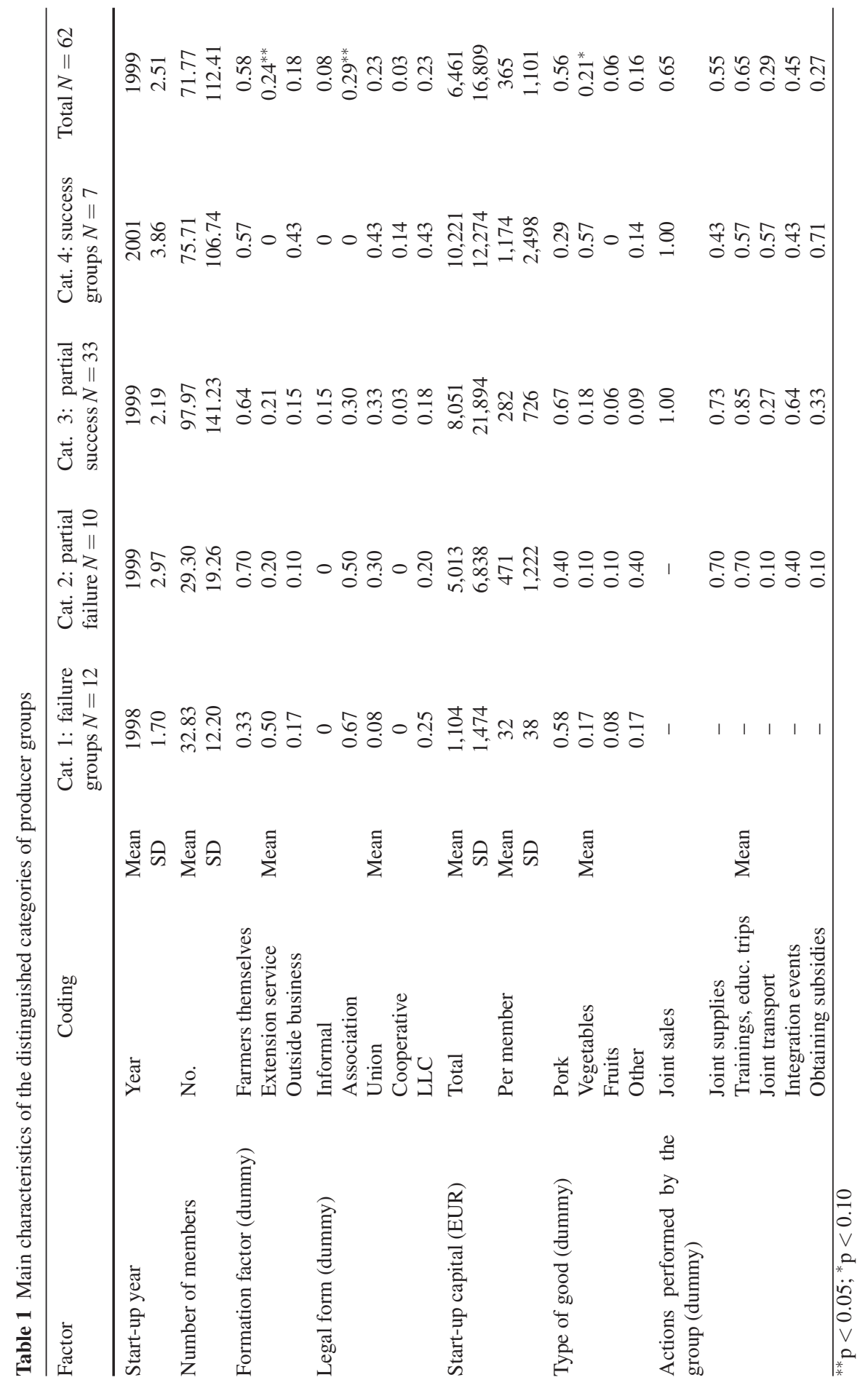


by the high standard deviation. The smallest group had only five members, the largest 700. The role of leadership in decision-making was measured by asking the interviewed producer group leaders whether they make most group decisions. The mean for the answers to the question reached 2.8 on a scale of $1-4$, in which 1 stood for disagree and 4 for agree. Selection of partners for the alliance was measured by asking whether there was a selection process of members during the group's formation stage. This had happened in 31\% of the groups. The existence of a previous business relationship was measured by asking the interviewed leaders whether one had existed with most of the group members. Fourteen percent of them fully agreed with this statement, $9.7 \%$ partially agreed, $14.5 \%$ partially disagreed, and $61.3 \%$ disagreed entirely.

Regarding communication among the members, we asked the interviewees whether all members were involved in the initial stage of planning and designing the group. In $30.6 \%$ of the groups, all members were involved in the discussion; in $64 \%$ of the groups only some members were involved; and in $4.8 \%$ of the groups the decisions were made exclusively by the initiative actor, and there was no discussion with other members. Group homogeneity was measured by asking the interviewees whether members of their groups had similar economic potential. Sixteen percent of groups were homogenous. To measure competition we investigated how the interviewees evaluated market relationships with the main competitors of producer groups - middlemen. Fourteen and a half percent of the groups reported experiencing harsh competition with middlemen, and 30.6\% found them minor competitors. Table 2 presents summary statistics for the distinguished independent variables.

\subsection{Regression Modeling Results}

In order to measure the impact of the independent variables above on the distinguished categories of the success of producer groups, we ran an ordinal probit regression. A few pairs of independent variables were correlated with each other. The regression was thus run stepwise. The cut significance level was defined as $p<0.1$. The regression results are presented in Table 3.

The strongest impact on the likelihood of producer group success was achieved by the variables indicating whether the members had had a previous business relationship and by the variable indicating whether there was a selection process in choosing the members at the group's formation stage. The variables were additionally correlated $(p<0.01)$. The finding supports Hypothesis 3 derived mainly from the theoretical prediction that the key element for the success of hybrid modes of governance is the selection of partners based on previous experience in market relationships. It might also explain the failure of the large proportion of producer groups that were established on the initiative of the extension service. We might suspect that, while the extension service officials aimed at forming a producer group and encouraged all farmers in the area to join the group, the groups formed in alternative ways were more selective and careful about choosing potential partners. 
Table 2 Summary statistics for the independent variables

\begin{tabular}{|c|c|c|c|c|c|c|c|}
\hline Variable & Measurement & Coding & $N$ & Mean & SD & Min & Max \\
\hline Group size & Number of members & Number & 62 & 71.77 & 112.41 & 5 & 700 \\
\hline $\begin{array}{l}\text { Leader's } \\
\text { decision-making } \\
\text { strength }\end{array}$ & $\begin{array}{l}\text { Does the leader make } \\
\text { most of decisions in the } \\
\text { group? }\end{array}$ & $\begin{array}{l}\text { 1-disagree, } \\
\text { 2-rather } \\
\text { disagree, } \\
\text { 3-rather agree, } \\
\text { 4-agree }\end{array}$ & 62 & 2.81 & 1.01 & 1 & 4 \\
\hline $\begin{array}{l}\text { Selection of } \\
\text { members }\end{array}$ & $\begin{array}{l}\text { Was there any selection } \\
\text { process for the } \\
\text { members? }\end{array}$ & Yes-1, no- -0 & 62 & 0.31 & & 0 & 1 \\
\hline $\begin{array}{l}\text { Business } \\
\text { acquaintance }\end{array}$ & $\begin{array}{l}\text { Did the members have } \\
\text { business relationships } \\
\text { before establishing the } \\
\text { group? }\end{array}$ & $\begin{array}{l}\text { 4-all had, } \\
\text { 3-majority, } \\
\text { 2-some, 1-none }\end{array}$ & 62 & 1.77 & 1.12 & 1 & 4 \\
\hline $\begin{array}{l}\text { Communication } \\
\text { among members }\end{array}$ & $\begin{array}{l}\text { Were all the members } \\
\text { involved in the initial } \\
\text { discussion about the } \\
\text { group? }\end{array}$ & $\begin{array}{l}\text { 1-none, 2-some, } \\
\text { 3-all }\end{array}$ & 62 & 2.26 & 0.54 & 1 & 3 \\
\hline Homogeneity & $\begin{array}{l}\text { Do members have } \\
\text { similar economic } \\
\text { potential? }\end{array}$ & 1-yes, no-0 & 62 & 0.16 & & 0 & 1 \\
\hline Competition & $\begin{array}{l}\text { How would you } \\
\text { evaluate the competition } \\
\text { with the middlemen on } \\
\text { the market? }\end{array}$ & $\begin{array}{l}\text { 3-major } \\
\text { competition, } \\
2 \text {-minor } \\
\text { competition, } \\
\text { 1-no competition }\end{array}$ & 62 & 1.60 & 0.73 & 1 & 3 \\
\hline
\end{tabular}

Table 3 Stepwise ordinal probit regression results

\begin{tabular}{lc}
\hline Independent variables & $\begin{array}{c}\text { Dependent variable } \\
\text { Category of success: } 1-4\end{array}$ \\
\hline No. of members & $0.003^{* *}$ \\
& 0.001 \\
Leader's strength & $0.270^{*}$ \\
Selection of members & 0.150 \\
& $1.037^{* * *}$ \\
Business acquaintance & 0.376 \\
& $0.526^{* * *}$ \\
Pseudo $\mathrm{R}^{2}$ & 0.166 \\
No. of observation & 0.209 \\
${ }^{* * *} \mathrm{p}<0.01 ;{ }^{* *} \mathrm{p}<0.05 ;{ }^{*} \mathrm{p}<0.10$ & 62 \\
\hline
\end{tabular}

A significant negative correlation was found between the variable indicating whether the group was formed due to an initiative of the extension service and the variable indicating whether there was a process of member selection $(p<0.1)$. 
Additionally, in comparison with the findings of Banaszak and Beckmann (2006: 18), we might stipulate that the quality of the previous relationships also matters. Ordinary earlier acquaintance among producer group members based on neighborhood, friendship and family relationships had a negative impact on the deviation rate in the group (Banaszak and Beckmann, 2006: 18).

The variable that had the second strongest significant positive impact on the likelihood of producer group success was the group size. The larger the group, the more likely it was to be successful. This supports this part of the theory formulated in Hypothesis 1, which proposed that larger organizations are more likely to decrease per unit transaction costs, and that in addition, larger groups are less vulnerable to the danger of internal rent seeking and opportunistic behavior.

Our finding that success is positively related to group size is somewhat in opposition to the discussion on the provision of collective benefits. Olson (1965) argued that larger groups find it harder to communicate and coordinate their actions, which was expected to hinder cooperation. We might stipulate that leadership is the factor that counteracts the negative impact of enlarging group size on communication and coordination costs. This corresponds to the finding that the variable indicating leadership decision-making strength was also significant. The stronger the leader, the more likely the group was to be successful. This confirms Hypothesis 2 which stated that leadership contributes to saving on internal transaction costs, facilitates coordination, makes monitoring and punishing more feasible, and thus has a positive impact on forming successful producer groups. Additionally, since producer groups operate in market settings, increasing the number of members and decreasing transaction costs might also increase the group's bargaining power and thus provide higher benefits to members.

The second part of Hypothesis 2 suggested that a strong and dominant leader who captures information is a threat to the continuity of relationships in hybrids and therefore decreases the chances of having a successful hybrid arrangement. The findings from Banaszak and Beckmann (2007: 186) suggest that this might also be the case. Leaders' decision-making power had a significant positive impact on the likelihood of the group entering a long-term contract. Nonetheless, as suggested in Banaszak and Beckmann (2006: 18), selling group products through a long-term contract increases the likelihood of playing a prisoner's dilemma game and thus might potentially increase deviation rates.

\section{Conclusions}

The main question posed in the article investigated determinants of success of cooperative arrangements functioning in agricultural markets. The question was investigated using empirical data collected on agricultural producer groups functioning in Poland. The literature review resulted in six hypotheses. The hypotheses were operationalized into seven independent variables. We measured the impact of the variables on four categories of success using the technique of ordinal probit regression. 
The findings correspond to the results obtained by Ziegenhorn (1999: 66), who pointed out that leadership, knowledge, and selection of network participants influence compatibility. We show, however, that the quality of the knowledge of the participants is also important and should be based on previous business acquaintance.

The most significant impact on the likelihood of group success was achieved by the variables indicating whether the members had had a business relationship before establishing the group, as well as the variable indicating whether there was a member selection process during the group's formation. Both variables were strongly correlated as well. In accordance with the theoretical predictions, we found out that the key to the success of hybrid modes of governance, such as producer groups, is the selection of partners based on previous experience in market relationships. This finding might provide another explanation for the failure of such a large proportion of producer groups established on the initiative of the extension service. We might suspect that extension service officials just wanted to form producer groups and encouraged all farmers in an area to join a group, while groups formed in alternative ways were more selective and careful about choosing the potential partners. A significant negative correlation was found between the variable indicating whether the group was formed by an initiative of the extension service and the variable indicating whether there was a member selection process.

The third variable with a significant positive impact on the likelihood of producer group success was group size. The larger the group, the more likely it was to be successful. This is in line with the hypothesis that suggested that large organizations on the one hand might decrease transaction costs, and on the other hand lower the danger of internal rent seeking and opportunistic behavior.

The last variable with a positive impact on the likelihood of success was leadership strength. As suggested by the reviewed theories, leadership might decrease internal transaction costs and thus make the organization more competitive, and leadership increases the chances of coordinating members on efficient equilibria and facilitates cooperation.

The analysis of the differences between the distinguished categories of success of producer groups shows the significant impact of a formal institutional environment. Both the role of the extension service and the choice of the legal form of cooperation seem to considerably affect the groups' functioning. There is a need for future research to explore this problem further. Additionally, our interpretation of success corresponds to the interviewed group leaders' understanding of success. We did not, however, interview group members. An area for further research could be to collect data at the member level and investigate how our findings are related to their understanding of successful cooperation.

Acknowledgements The research was supported by the Integrated Development of Agriculture and Rural Institutions in Central and Eastern European Countries Project (IDARI) funded within the Fifth Framework Program of the European Commission. The author gratefully acknowledges very helpful comments on the paper given by Volker Beckmann, Konrad Hagedorn, Piotr Matczak, Christiaan Hogendorn, Julian Rode, and an anonymous referee. 


\section{References}

Ahn, T.K., Ostrom, E., Schmidt, D., Shupp, R. and Walker, J. (2001). Cooperation in PD games: Fear, greed, and history of play. Public Choice, 106(1-2), 137-155.

Axelrod, R. (1984). The Evolution of Cooperation. New York: Basic Books.

Banaszak, I. (2006). Producer groups in Poland. Empirical survey results. Annals of the Polish Association of Agricultural and Agribusiness Economists, 7(6), 5-10.

Banaszak, I. and Beckmann, V. (2006). Compliance with Rules and Sanctioning in Producer Groups in Poland. IDARI Working Paper, Humboldt University of Berlin.

Banaszak, I. and Beckmann, V. (2007). The role of leadership in establishing and sustaining cooperation. Evidence from producer groups in Poland. In: A. Knierim, U.J. Nagel, and C. Schäfer (Eds.), Managing Economic, Social and Biological Transformations. Proceedings of the First Green Week Scientific Conference (pp. 180-187). Weikersheim: Margraf Publishers.

Bianco, W.T. and Bates, R.H. (1990). Cooperation by design: Leadership, structure, and collective dilemmas. The American Political Science Review, 84(1), 133-147.

Binger, B.R. and Hoffman, E. (1989). Institutional persistence and change: The question of efficiency. Journal of Institutional and Theoretical Economics, 145, 67-84.

Bonus, H. (1986). The cooperative association as a business enterprise: A study in the economics of transactions. Journal of Institutional and Theoretical Economics, 142, 310-339.

Borgen, S.E. (2004). Rethinking incentive problems in cooperative organizations. Journal of SocioEconomics, 33, 383-393.

Bowersox, D.J., Closs, D.J. and Stank, T.P. (1999). 21st Century Logistics: Making Supply Chain Integration a Reality. Oak Brook: Council of Logistics Management.

Brosig, J. and Weimann, J. (2003). The effect of communication media on cooperation. German Economic Review, 4(2), 217-241.

Bruynis, C., Hahn, D.E. and Taylor, W.J. (1997). Critical success factors for emerging agricultural marketing cooperatives. American Cooperation, 50-54 [An annual publication of the National Council of Farmer Cooperatives, Washington, DC.].

Caputo, M. and Mininno, V. (1996). Internal, vertical and horizontal logistics integration in Italian grocery distribution. International Journal of Physical Distribution and Logistics Management, 26(9), 64-90.

Ejsmont, J. and Milewski, R. (2005). Podstawy prawne tworzenia i dzialalności grup producentów. A guide for farmers. Warszawa: Fundacja Wspomagania Wsi. http://www.witrynawiejska. org.pl/images/15208_grprod.pdf. Cited 25 May 2007.

Foss, N.J. (1999). Understanding leadership: A coordination theory. DRUID Working Paper No. 99-3.

Haag, M. and Lagunoff, R. (2003). On the size and structure of group cooperation. Fondazione Eni Enrico Mattei Working Paper No. 54.2003, Georgetown University Working Paper No. 03-02.

Hansmann, H. (1996). The Ownership of the Enterprise. Cambridge, London: The Belknap Press of Harvard University Press.

Hendrikse, G.W.J. (2007). Two vignettes regarding boards in cooperatives versus corporations: Irrelevance and incentives. In: K. Karantininis and J. Nilsson (Eds.), Vertical Markets and Cooperative Hierarchies (pp. 137-150). Dordrecht: Springer.

Kleindorfer, P.R., Kunreuther, H.C. and Schoemaker, P.J.H. (1993). Decision Sciences. An Integrative Perspective. Cambridge: Cambridge University Press.

Kollock, P. (1998). Social dilemmas: The anatomy of cooperation. Annual Review of Sociology, 24, 183-214.

Kräkel, M. (2006). On the "adverse selection" of organizations. IZA Discussion Paper, University of Bonn.

Kreps, D.M. (1996). Markets and hierarchies and (mathematical) economic theory. Industrial and Corporate Change, 5(2), 561-595.

Lemanowicz, M. (2005). Organizacje i grupy producentów szansa na poprawę konkurencyjności polskiego rolnictwa. Warszawa: Wydawnictwo SGGW. 
Long, J.S. and Freese, J. (2001). Regression Models for Categorical Dependent Variables Using Stata. College Station: Stata Press.

Ménard, C. (2004). The economics of hybrid organizations. Journal of Institutional and Theoretical Economics 160, 345-376.

Ménard, C. (2005). A new institutional approach to organization. In: C. Ménard, Shirley M. (Eds.), Handbook of New Institutional Economics (pp. 281-318). New York: Springer.

Ménard, C. (2006). Hybrid organization of production and distribution. Revista de Análisis Económico, 21(2), 25-41.

Milgrom, P.R. (1988). Employment contracts, influence activities, and efficient organization design. The Journal of Political Economy, 96(1), 42-60.

Miller, G.J. (1992). Managerial Dilemmas. The Political Economy of Hierarchy. New York: Cambridge University Press.

Olson, M. (1965). The Logic of Collective Action. Public Goods and the Theory of Groups. Cambridge, London: Harvard University Press.

Pallant, J. (2001). SPSS Survival Manual. A Step by Step Guide to Data Analysis Using SPSS for Windows (Version 10). Buckingham: Open University Press.

Schaefer, S. (1998). Influence costs, structural inertia, and organizational change. Journal of Economics and Management Strategy, 7(2), 237-263.

Sexton, R.J. and Iskow, J. (1988). Factors critical to the success or failure of emerging agricultural cooperatives. Giannini Foundation Information Series, 88(3). http://ageconsearch.umn.edu/ bitstream/123456789/24368/1/is880003.pdf. Cited 8 May 2007.

Shamir, B., House, R. and Arthut, M.B. (1993). The motivational effects of charismatic leadership: A self-concept based theory. Organization Science, 4(4), 577-594.

Spulber, D.F. (1999). Market Microstructure: Intermediaries and the Theory of the Firm. Cambridge: Cambridge University Press.

Whipple, J.M. and Frankel, R. (2000). Strategic alliance success factors. The Journal of Supply Chain Management: A Global Review of Purchasing and Supply, August, 21-28.

Williamson, O.E. (1983). Markets and Hierarchies: Analysis and Antitrust Implications. New York: The Free Press.

Ziegenhorn, R. (1999). Networking the Farm. The Social Structure of Cooperation and Competition in Iowa Agriculture. Aldershot, Vermont: Asgate. 